\title{
Bioadsorption of Heavy Metals From Industrial Wastewater Using Some Species of Bacteria
}

\author{
Fikrat M. Hassan* Adnan N. A. R. AL-Baidhani** \\ Sahira H. H. Al-Khalidi****
}

*Department of Biology, College of Science for Women, University of Baghdad, Iraq.

**Department of Biology, College of Education for Pure Sciences, University of Diyala, Iraq.

***Educational Directorate, Ministry of Education, Diyala, Iraq.

Received 9/6 /2016

Accepted 13/6/2016

(c) (1) $(9)$

NoDerivatives 4.0 International Licens

\begin{abstract}
:
Three isolated bacteria were examined to remove heavy metals from the industrial wastewater of the Diala State Company of Electrical Industries, Diyala-Iraq. The isolated bacteria were identified as Pseudomonas aeruginosa, Escherichia coli and Sulfate Reducing Bacteria (SRB). The three isolates were used as an adsorption factor for different concentrations of Lead and Copper (100, 150, and $200 \mathrm{ppm}$.), in order to examine the adsorption efficiency of these isolates. In addition, the effect of three factors on heavy metals adsorption were examined; temperature $(25,30$, and $\left.37^{\circ} \mathrm{C}\right), \mathrm{pH}(3$ and 4.5$)$ and contact time ( 2 and $24 \mathrm{hrs}$ ). The results showed that the highest level of lead adsorption was obtained at $37{ }^{\circ} \mathrm{C}$ by E. coli, $P$, aerugenosa and SRB with percentage of $95,95.3$ and $99.7 \%$ respectively, whereas, E. coli, $P$. Aerugenosa and SRB gave a copper adsorption percentage of $(40.63,50.51$ and $80.57 \%$ ) respectively at $37^{\circ} \mathrm{C}$. Moreover, E.coli showed different percentage of metal adsorption ranged from $6.4 \%$ to $95 \%$ with lead concentration of 100 and $200 \mathrm{ppm}$ at pH4.5 and for each of 2 and 24 hrs contact time, whereas, it exerts percentage of copper adsorption ranged from $3.5 \%$ to $40.63 \%$ at 100 and $200 \mathrm{ppm}$ and pH value of 4.5 for similar contact time. P. aerugenosa was also shown to be involved in metal adsorption with percentage ranged from $1.39 \%$ for lead concentration of $150 \mathrm{ppm}$ to $97.9 \%$ for $200 \mathrm{ppm}$ under $\mathrm{pH}$ of 3 and contact times of 2 and $24 \mathrm{hrs}$. Interestingly, SRB exhibits significant differences in metal absorption values ranged from $14.97 \%$ for lead (100 ppm) to $99.32 \%$ at $200 \mathrm{ppm}$ with a $\mathrm{pH}$ value of 3 and contact times of 2 and $24 \mathrm{hrs}$ and under different temperatures.
\end{abstract}

Key words: Bioremediation, Bioremoval, treatment plant, E. coli, P. aeruginosa and SRB, Idustrial wastewater

\section{Introduction:}

Water pollution occurs when environments without treatment, which
wastewater is introduced into in turn changes the water quality and 
have a negative effect on the existent microorganisms [1]. Water quality refers to the concentrations of both organic and inorganic pollutant in water and changes in water properties [2]. The chemical and physical changes in water and their effect on organisms became a major problem worldwide, which is potentially due to the massive industrial developments. Generally, water pollutants are either natural like fires and volcanoes and degradation of organic and inorganic materials, or others resulted from human nature like discarded the industrial waste in water environment, deforestation, mining, treatment of waste water and Fertilizers Industry [3].

Industrial waste is water that carries heavy metal residues resulted from manufacturing processes and caused environmental problems, therefore, several physical and chemical treatment units were used to remove these pollutants from the industrial wastes, however, these methods are highly cost and not applicable [4].

Recently, the treatment of heavy metal has gained more attention due to the significant increase in pollution by these elements, as a product of industrial and agricultural process and mining [5]. Furthermore, because of the industrial development, heavy metal became widely distributed and is considered to be the most harmful type of pollution as it cannot be degraded naturally, and it accumulates in the organisms and transmitted to human through the food chain $[6,7]$. These elements are harmful for human by direct uptake or by accumulation in the tissues of some organisms that consumed by human [8]. Several studies were focused on the importance of heavy metals that exsisting in the environment such as mercury, lead, zinc and chromium. Many scientists classified these elements according to their importance of and their effect in nature. Generaly, heavy metals are shared specific properties like; the heavy metals are poisonous and not able to degrade in nature, they are able to transform from low poisoning to high poisoning in the environment.and their ability to accumulate in the food chain and their effect on the activity of the physiological functions in human and other organisms [9].

The importance of some bacteria resides in the presence of the cell wall; the external component of bacterial cell structure; that is composed of peptidoglycan and is located under the plasma membrane [10]. Bacterial cell wall plays an important role in biosorption and heavy metal removal, due to the presence of variety of functional sites such as; carboxyl, amino, hydroxyl moiety, phosphate and sulphydryl [11]. Moreover, the bacteria are considered to be more efficient absorbent than other organisms for several reasons:

- They are able to grow under different conditions, and are tolerant to a wide range of environmental stress, in addition to their availability in nature and easy to collect [12]

- High surface-volume ratio [13].

- The cell wall properties exhibit anionic net charge to the surface [14].

- The bacterial cells are able to undergo to genetic modification in order to increase the adsorption efficacy [15].

- It has been reported that some bacterial species produce proteins that is induced by heavy metals Methalothionine, which are able to bind metallic cations and remove their effects [16].

The treatment plant of the Diala State Company of Electrical Industries, Diyala-Iraq is lacking the biological treatment and not efficient to remove heavy metals from the industrial wastewater [17]. These reasons are justified by this study. The objective of this study was to isolate bacteria from 
the plant and examine their ability to adsorb the heavy metals.

\section{Material and Methods: Sample collection}

Bacterial samples were collected from industrial and household wastewater plant of the Diala State Company of Electrical Industries and in both cases of after and before treatment. Samples were collected in sterile containers of $1 \mathrm{~L}$ and stored in cooled box, and transformed directly to the laboratory. The current study was performed from November and December 2014 to January, February and March of 2015.

\section{Heavy metal stock solutions}

A $1.5985 \mathrm{mg}$ of $\mathrm{Pb}\left(\mathrm{NO}_{3}\right)_{2}$ was dissolved in 11 of deionised distilled water $\left(\mathrm{ddH}_{2} \mathrm{O}\right)$ to get a stock solution of $1000 \mathrm{ppm}$. The stock solution was filter sterilized $(0.45 \mu \mathrm{m})$ and different concentrations were prepared and used. A $2.115 \mathrm{mg}$ of copper chloride $\mathrm{CuCl}_{2}$ was dissolved in 11 of $\mathrm{ddH}_{2} \mathrm{O}$ to get a final concentration of 1000 ppm stock solution. The stock was filter sterilized $(0.45 \mu \mathrm{m})$ before serial concentration were being prepared APAH [18].

\section{Isolation and identification of bacteria Identification of $\boldsymbol{E}$. coli}

E. coli was identified by their growth properties on MacConkey agar. Bacterial colonies appeared to be small, smooth and dry, spherical shape and red colour (lactose fermenting). The Microscopic examination was conducted and confirmed that E. coli was Gramnegative and rod shape. Biochemical tests were also performed for further identification steps according to [19].

\section{Identification of $\boldsymbol{P}$. aeruginosa}

$P$. aeruginosa was identified by subculturing the bacteria on nutrient agar at $37{ }^{\circ} \mathrm{C}$ for $24 \mathrm{hrs}$. The colonies appeared to be large, spherical with smooth shape, concave and have undesired smell. Bacteria produce pale colonies when grown on MacConkey, and thus refers to the non lactose fermenting, whereas, it produces the pyocine stain when grown on King B agar. $P$. aeruginosa was also shown to be positive to the oxidase test. Microscopic examination was done in order to confirm the identity of this type of bacteria, and showed that bacterial cells are Gram-negative, rod shape and non spore forming. The isolate was subjected to biochemical test to confirm the identity, according to [19].

\section{Identification of Sulfate reducing bacteria SRB}

A total of 20 isolates of SRB were obtained from industrial waste water at $20 \mathrm{~cm}$ depth, the identification of SRB was performed according to [20]. The SRB was isolated and purified under anaerobic conditions using $\mathrm{N}_{2}: \mathrm{CO}_{2}$ ratio at $20: 80 \%$ in the presence of oxygen reduction elements. Bacterial colonies appeared in black colour when it grown on API agar after 1-3 days at $37^{\circ} \mathrm{C}$. Microscopic examination showed that SRB was spherical shape, regular edges and large. After 3 to 5 days, the colonies turned to black, and this due to the presence of iron in the media which binds to the sulphur resulted from sulphate reduction to produce black ferrous sulphide which is an indication for SRB. SRB was further purified using API broth media which contains lactate that is considered to be an energy source, and suitable for growing up to $80 \%$ of SRB. In addition, the broth was also contains sulphate source that is needed for SRB growth such as ammonium ferrous sulphate and magnesium sulphate, in addition to oxygen reduction elements. Moreover, using of sodium bicarbonate solution as a buffer solution and a source for carbon dioxide [21], and also includes reduction factors like Sodium dithionite and cystine, which is to be a selective medium for isolation and purification of 
SRB. Like E. coli and $P$. aeruginosa, SRB was subjected to biochemical tests.

\section{Results and Discussion:}

The physicochemical factors and the efficiency of treatment plant of the Diala State Company of Electrical Industries were studied by Hassan et al. [17]. The evaluation study of the treatment plant shown that the heavy metals concentrations were not affected by the treatment process in the plant.

The effect of different factors on bioremoval process

Temperature

Temperature is considered to be the most effective factor on adsorption process, Turan et al. [22] mentioned that the adsorption process is endothermic. Results showed that the adsorption level was increased in high temperatures (Fig. 1), the highest level of lead adsorption was recorded at 37 ${ }^{\circ} \mathrm{C}$, for $E$. coli which gaves a percentage of $95 \%$ ( $\mathrm{LSD}=7.025$ at $\mathrm{p}<0.05)$. $P$. aerugenosa was showed high level of lead adsorption for about $95.3 \%$ ( LSD $=6.33$ at $\mathrm{p}<0.05)$, whereas, SRB exhibits the highest level of lead adsorption of $99.07 \%$ at the same LSD value, in comparison to $E$. coli and $P$. aeruginosa.

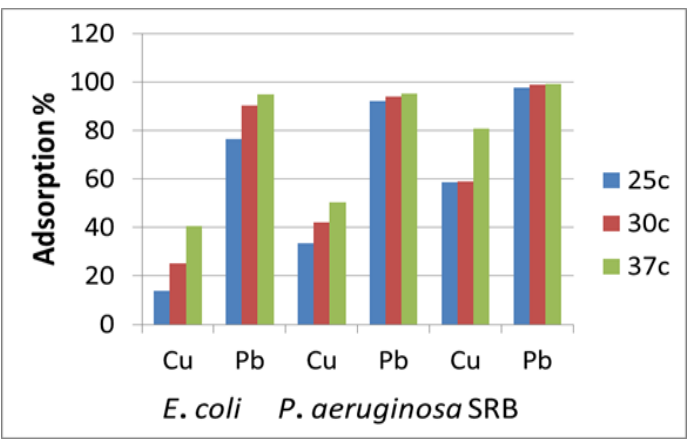

Fig. 1: The percentage of adsorption by the studied bacteria under different temperatures

In this study the results were clearly showd that the temperature has a great effect on copper adsorption, and $37^{\circ} \mathrm{C}$ is the ideal temperature for copper adsorption by the isolated bacteria, as $E$. coli was able to adsorbe for about $40.63 \% \quad(\mathrm{LSD}=8.52$ at $\mathrm{p}<0.05)$, and $50.51 \%$ and $91.36 \%$ (LSD $=7.31$ at $\mathrm{p}<0.05)$ and 8.44 were obtained from $P$. aeruginosa and SRB, respectively (Table1- 3). Paranthaman and Karthikeyan [23] has mentioned that the range of lead adsorption by $P$. aeruginosa was increased significantly under temperatures ranged from 25-30 ${ }^{\circ} \mathrm{C}$. Another study was mentioned that chromium uptake was increased with increasing the temperatures below 40 ${ }^{\circ} \mathrm{C}$, when E. coli and $P$. aeruginosa where used [24]. In contrast, the chromium adsorption decreased when temperatures increased to $50{ }^{\circ} \mathrm{C}$. It has been reported that the adsorption of lead and chromium was increased by increasin the temperature to $50{ }^{\circ} \mathrm{C}$ by $P$. aeruginosa [25]. In another study of using algae for some elements adsorption, it is found that the best temperature for adsorption is ranged from $15-35{ }^{\circ} \mathrm{C}$ at concentration of 50 ppm [26]. Furthermore, AbduSattar [27] was suggested that $30{ }^{\circ} \mathrm{C}$ is the ideal temperature for cobalt adsorption by using orange peels. Moreover, Vijayaraghavan and Yan [28] was reported that the sharp increase or decrease in temperatures caused shrinkage of adsorption cells, and in turns lead to reduce the adsorption surface area and therefore reduction in adsorption levels.

pH

The results of this study clearly demonstrate that the best $\mathrm{pH}$ value for copper and lead adsorption is at $\mathrm{pH} 4.5$ by using of $E$. coli and $P$. aeruginosa, compared to $\mathrm{pH} 3$ (Figure 2). It showed that $P$. Aeruginosa exert a high level of copper and lead adsorption percentage of about $95 \%$ and $50.51 \%$, whereas, it was $95 \%$ and $40.36 \%$ for copper and lead respectively by using of $E$. coli (Table1-3). The SRB was showed a significant adsorption percentage of 
91.36 at $\mathrm{pH} 3$ in comparison to $\mathrm{pH} 4.5$, whereas, there is no different in lead adsorption at $\mathrm{pH} 3(99.06 \%)$ and $\mathrm{pH}$ $4.5(99.07 \%)$.

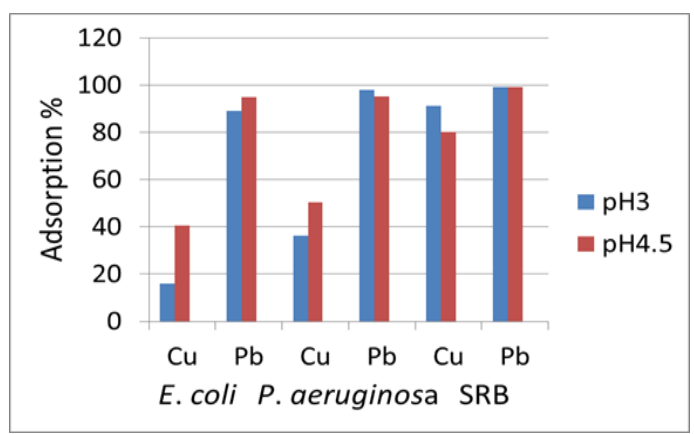

Fig. 2: The adsorption percentage of copper and leads by the studied bacteria at different $\mathrm{pH}$

Table 1: The percentage of heavy metals adsorption by $E$. Coli at different temperature, $\mathrm{pH}$ and contact time

$\mathrm{pH} 3$ and $2 \mathrm{hrs}$

\begin{tabular}{|c|c|c|c|c|c|}
\hline & \multicolumn{4}{|c|}{ Temperature ${ }^{\circ} \mathrm{C}$} & \\
\hline & & 25 & 30 & 37 & LSD \\
\hline \multirow{3}{*}{$\begin{array}{c}\tilde{2} \\
2 \\
0 \\
0\end{array}$} & 100 & 30.46 & 39.72 & 67.56 & $9.68 *$ \\
\hline & 150 & 63.75 & 64.25 & 82.16 & 9.47* \\
\hline & 200 & 84 & 85.86 & 89 & $10.52 \mathrm{NS}$ \\
\hline \multicolumn{2}{|c|}{ LSD } & $11.59^{*}$ & $9.75^{*}$ & $9.02^{*}$ & \\
\hline
\end{tabular}

$\mathrm{pH} 3$ and $24 \mathrm{hrs}$

\begin{tabular}{|c|c|c|c|c|c|}
\hline \multicolumn{5}{|c|}{$\mathrm{pH} 4.5$ and $2 \mathrm{hrs}$} & $\mathrm{pH}$ \\
\hline \multirow{5}{*}{ 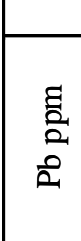 } & \multicolumn{4}{|c|}{ Temperature ${ }^{\circ} \mathrm{C}$} & \multirow[b]{2}{*}{ LSD } \\
\hline & & 25 & 30 & 37 & \\
\hline & 100 & 10.08 & 28.62 & 77.21 & 9.431 \\
\hline & 150 & 70.14 & 71.84 & 92.57 & $6.509 *$ \\
\hline & 200 & 76.53 & 90.24 & 95 & $7.025^{*}$ \\
\hline LSD & & $9.021 *$ & $8.562^{*}$ & $6.305 *$ & \\
\hline
\end{tabular}

pH3 and 2hrs

\begin{tabular}{|c|c|c|c|c|c|}
\hline & & Temp & ature $^{\circ}$ & & \\
\hline & & 25 & 30 & 37 & $\overline{L S D}$ \\
\hline है & 100 & 3.87 & 6.91 & 9.28 & $3.86^{*}$ \\
\hline $\bar{U}$ & 150 & 7.12 & 8.75 & 14.27 & $5.29 *$ \\
\hline & 200 & 5.67 & 11.69 & 16.07 & $5.63^{*}$ \\
\hline LSD & & $2.035^{*}$ & $2.485^{*}$ & $2.511 *$ & \\
\hline
\end{tabular}

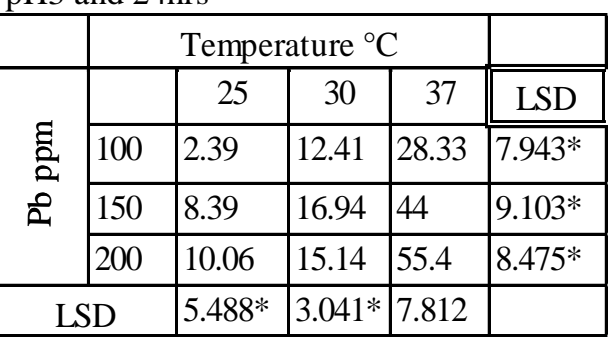

pH4.5 and $2 \mathrm{hrs}$

\begin{tabular}{|c|c|c|c|c|c|}
\hline & & Temp & ature & & \\
\hline & & 25 & 30 & 37 & LSD \\
\hline ถี & 100 & 6.4 & 6.92 & 8.08 & $3.41 \mathrm{NS}$ \\
\hline 2 & 150 & 44.14 & 48.14 & 49.49 & $5.52 \mathrm{NS}$ \\
\hline & 200 & 47.03 & 70.89 & 76.53 & $8.95^{*}$ \\
\hline $\mathrm{SD}$ & & $8.32 *$ & $8.96^{*}$ & $7.68 *$ & \\
\hline
\end{tabular}

$\mathrm{pH} 3$ and $24 \mathrm{hrs}$

\begin{tabular}{|c|c|c|c|c|c|}
\hline & \multicolumn{4}{|c|}{ Temperature ${ }^{\circ} \mathrm{C}$} & \\
\hline \multirow{4}{*}{$\underset{己}{Z}$} & & 25 & 30 & 37 & LSD \\
\hline & 100 & 7.89 & 13.89 & 17.22 & $5.093 *$ \\
\hline & 150 & 9.07 & 14.21 & 14.33 & $4.69 *$ \\
\hline & 200 & 13.87 & 25.31 & 40.63 & $8.52^{*}$ \\
\hline \multicolumn{2}{|c|}{ LSD } & $4.522 *$ & $6.85^{*}$ & $6.53 *$ & \\
\hline
\end{tabular}

pH 4.5 and $24 \mathrm{hrs}$

\begin{tabular}{|c|c|c|c|c|c|}
\hline & \multicolumn{4}{|c|}{ Temperature ${ }^{\circ} \mathrm{C}$} & \\
\hline \multirow{4}{*}{ 己 } & & 25 & 30 & 37 & LSD \\
\hline & 100 & 2.07 & 2.63 & 3.87 & $1.97 \mathrm{NS}$ \\
\hline & 150 & 3.36 & 5.27 & 5.71 & $2.66 \mathrm{NS}$ \\
\hline & 200 & 3.56 & 6.87 & 7.85 & 2.75 \\
\hline \multicolumn{2}{|c|}{ LSD } & $1.98 \mathrm{NS}$ & $2.407 *$ & $2.156^{*}$ & \\
\hline
\end{tabular}

$*(\mathrm{P}<0.05), \mathrm{NS}=$ Not Significant

\begin{tabular}{|c|c|c|c|c|c|}
\hline & \multicolumn{4}{|c|}{ Temperature ${ }^{\circ} \mathrm{C}$} & \\
\hline \multirow{4}{*}{ 己 } & & 25 & 30 & 37 & LSD \\
\hline & 100 & 3.5 & 4.83 & 5.53 & $2.33 \mathrm{NS}$ \\
\hline & 150 & 6.5 & 6.73 & 7.89 & $2.88 \mathrm{NS}$ \\
\hline & 200 & 8.25 & 11.03 & 13.82 & $3.594 *$ \\
\hline \multicolumn{2}{|c|}{ ISD } & 2.65 & $3.77 *$ & $3.91 *$ & \\
\hline
\end{tabular}


Table 2: The percentage of heavy metals adsorption by $P$. aerugenosa at different temperature, $\mathrm{pH}$ and contact time

\begin{tabular}{|c|c|c|c|c|c|}
\hline 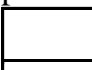 & \multicolumn{4}{|c|}{ Temperature ${ }^{\circ} \mathrm{C}$} & \\
\hline \multirow{4}{*}{$\begin{array}{l}\text { ב. } \\
2 \\
2 \\
0\end{array}$} & & 25 & 30 & 37 & LSD \\
\hline & 100 & 42.16 & 68.5 & 73.5 & $9.63^{*}$ \\
\hline & 150 & 57 & 80.1 & 93.28 & 7.97* \\
\hline & 200 & 85.22 & 88.28 & 97.9 & 7.44* \\
\hline LSD & & $13.49^{*}$ & $9.53 *$ & $8.94 *$ & \\
\hline
\end{tabular}

$\mathrm{pH} 3$ and $24 \mathrm{hrs}$

\begin{tabular}{l}
$\mathrm{pH} 4.5$ and $2 \mathrm{hrs}$ \\
\hline
\end{tabular}

\begin{tabular}{|c|c|c|c|c|c|}
\hline & \multicolumn{4}{|c|}{ Temperature ${ }^{\circ} \mathrm{C}$} & \\
\hline \multirow{4}{*}{$\begin{array}{l}\text { I. } \\
\text { 2. } \\
\text { 2. }\end{array}$} & & 25 & 30 & 37 & $\overline{\mathrm{LSD}}$ \\
\hline & 100 & 4.35 & 23.8 & 35.52 & $7.33^{*}$ \\
\hline & 150 & 1.39 & 36.98 & 53.5 & $9.08^{*}$ \\
\hline & 200 & 15.02 & 15.52 & 56.66 & $7.42 *$ \\
\hline & & $4.623^{*}$ & $6.549^{*}$ & $6.98 *$ & \\
\hline
\end{tabular}

$\mathrm{pH} 4.5$ and $24 \mathrm{hrs}$

$\mathrm{pH} 3$ and $2 \mathrm{hrs}$

\begin{tabular}{|c|c|c|c|c|c|}
\hline \multicolumn{6}{|c|}{ erature ${ }^{\circ} \mathrm{C}$} \\
\hline \multirow{4}{*}{$\underset{z}{\tilde{z}}$} & & 25 & 30 & 37 & $\overline{\mathrm{LSD}}$ \\
\hline & 100 & 7.44 & 17.64 & 18.84 & 5.96* \\
\hline & 150 & 7.67 & 18.06 & 21.27 & $7.02^{*}$ \\
\hline & 200 & 10.67 & 33.49 & 36.23 & $7.44 *$ \\
\hline \multicolumn{2}{|c|}{ LSD } & $4.32 \mathrm{NS}$ & $6.59 *$ & $6.42 *$ & \\
\hline
\end{tabular}

\begin{tabular}{|c|c|c|c|c|c|}
\hline & \multicolumn{4}{|c|}{ Temperature ${ }^{\circ} \mathrm{C}$} & \\
\hline \multirow{4}{*}{$\begin{array}{l}\tilde{a} \\
\frac{0}{2} \\
\frac{0}{2}\end{array}$} & & 25 & 30 & 37 & $\begin{array}{l}\text { LSD } \\
\end{array}$ \\
\hline & 100 & 446.72 & \begin{tabular}{|l|l|}
66.87 \\
\end{tabular} & 71.42 & $8.316^{*}$ \\
\hline & 150 & 57.86 & 72.79 & 77.53 & $8.027^{*}$ \\
\hline & 200 & \begin{tabular}{|l|l|}
72.79 \\
\end{tabular} & \begin{tabular}{|l|l|}
76.66 \\
\end{tabular} & 83.34 & $7.175^{*}$ \\
\hline \multicolumn{2}{|c|}{ LSD } & $8.925^{*}$ & $6.512^{*}$ & 6.967* & \\
\hline
\end{tabular}

$\mathrm{pH} 3$ and $24 \mathrm{hrs}$

pH4.5 and $2 \mathrm{hrs}$

$\mathrm{pH} 4.5$ and $24 \mathrm{hrs}$

\begin{tabular}{|c|c|c|c|c|c|}
\hline & & Tem & cature & & \\
\hline & & 25 & 30 & 37 & LSD \\
\hline है & 100 & 0.3 & 0.72 & 3.96 & $2.42^{*}$ \\
\hline$\vec{z}$ & 150 & 5.07 & \begin{tabular}{|l|l}
7.48 \\
\end{tabular} & \begin{tabular}{|l|}
9.86 \\
\end{tabular} & $2.98^{*}$ \\
\hline & 200 & 7.7 & 7.91 & 10.66 & $2.67 *$ \\
\hline & D & $2.45^{*}$ & $2.55^{*}$ & $3.08^{*}$ & \\
\hline
\end{tabular}

\begin{tabular}{|c|c|c|c|c|c|c|c|c|c|c|c|}
\hline $\mathrm{PH} 4.5$ & and & & & & $\overline{\mathrm{pH}}$ & and ? & thrs & & & & \\
\hline & & Tem & peratu & & & & & $\mathrm{Tem}$ & oerature & & \\
\hline & & 25 & 30 & 37 & LSD & & & 25 & 30 & 37 & $\begin{array}{l}\text { LSD } \\
\end{array}$ \\
\hline & 100 & 9.95 & 26.36 & 47.72 & $7.54 *$ & 릉 & 100 & 0.6 & 2.42 & 7.01 & $5.32 *$ \\
\hline בे & 150 & 11.98 & 47.86 & 40.08 & 9.36* & $\Rightarrow$ & \begin{tabular}{|l|}
150 \\
\end{tabular} & \begin{tabular}{|l|l|}
6.14 \\
\end{tabular} & \begin{tabular}{|l|}
9.81 \\
\end{tabular} & 10.18 & $4.92 \mathrm{NS}$ \\
\hline$\tilde{U}$ & 200 & 33.47 & 42.18 & 50.51 & 7.31* & & 200 & 5.41 & 9.78 & 36.9 & $7.43^{*}$ \\
\hline & & $7.63^{*}$ & $6.02^{*}$ & $4.389 \mathrm{NS}$ & & & & $3.29 *$ & $4.053^{*}$ & $7.22^{*}$ & \\
\hline
\end{tabular}


Table 3: The percentage of heavy metals adsorption by $S R B$ at different temperature, $\mathrm{pH}$ and contact time

$\mathrm{pH} 3$ and $2 \mathrm{hrs}$

\begin{tabular}{|c|c|c|c|c|c|}
\hline & \multicolumn{4}{|c|}{ Temperature ${ }^{\circ} \mathrm{C}$} & \\
\hline \multirow{4}{*}{$\begin{array}{c}\tilde{z} \\
\frac{2}{2} \\
\frac{0}{2}\end{array}$} & & 25 & 30 & 37 & LSD \\
\hline & 100 & 54.16 & 60.09 & 60.6 & $8.02 \mathrm{NS}$ \\
\hline & 150 & 67.05 & 78.58 & 89.5 & 7.98* \\
\hline & 200 & 76.48 & 87.92 & 91.36 & $8.44^{*}$ \\
\hline \multicolumn{2}{|c|}{ LSD } & 9.33* & $8.65^{*}$ & $9.72^{*}$ & \\
\hline
\end{tabular}

pH4.5 and $2 \mathrm{hrs}$

\begin{tabular}{|c|c|c|c|c|c|}
\hline & \multicolumn{4}{|c|}{ Temperature ${ }^{\circ} \mathrm{C}$} & \\
\hline \multirow{4}{*}{ 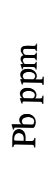 } & & 25 & 30 & 37 & LSD \\
\hline & 100 & 39.09 & 36.84 & 51.87 & $5.56^{*}$ \\
\hline & 150 & 41.12 & 55.85 & 60.25 & $11.02 *$ \\
\hline & 200 & 58.77 & 59.05 & 80.57 & $8.76^{*}$ \\
\hline \multicolumn{2}{|c|}{ LSD } & $7.09 *$ & $7.81 *$ & $9.32 *$ & \\
\hline
\end{tabular}

pH3 and 2hrs

\begin{tabular}{|c|c|c|c|c|c|}
\hline & \multicolumn{4}{|c|}{ Temperature ${ }^{\circ} \mathrm{C}$} & \\
\hline \multirow{4}{*}{ 己 } & & 25 & 30 & 37 & LSD \\
\hline & 100 & 90.24 & 98.84 & 99.14 & 7.54* \\
\hline & 150 & 93.67 & 99.02 & 99.06 & $8.02 \mathrm{NS}$ \\
\hline & 200 & 98.81 & 99.03 & 99.32 & $7.15 \mathrm{NS}$ \\
\hline & $7.31 *$ & 6.44NS & $6.02 \mathrm{~N}$ & \\
\hline
\end{tabular}

$\mathrm{pH} 4.5$ and $2 \mathrm{hrs}$

\begin{tabular}{|c|c|c|c|c|c|}
\hline & \multicolumn{4}{|c|}{ Temperature ${ }^{\circ} \mathrm{C}$} & \\
\hline \multirow{4}{*}{$\begin{array}{l}\tilde{z} \\
\text { : } \\
z \\
\text { U }\end{array}$} & & 25 & 30 & 37 & LSD \\
\hline & 100 & 92.65 & 97.85 & 98.13 & $7.98 \mathrm{NS}$ \\
\hline & 150 & 93.36 & 98.65 & 98.84 & $7.87 \mathrm{NS}$ \\
\hline & 200 & 97.69 & 98.78 & 99.07 & $6.33 \mathrm{NS}$ \\
\hline \multicolumn{2}{|c|}{ LSD } & $6.74 \mathrm{NS}$ & $5.41 \mathrm{NS}$ & 5.03 & \\
\hline
\end{tabular}

$*(\mathrm{P}<0.05), \mathrm{NS}=$ Not Significant

$\mathrm{pH}$ values play a great role in the adsorption, it is related to heavy metal removal using the microorganism. Its effect relies on the number of functional sites on the surface of the cell, and involve in diversity of heavy metal compounds [29]. Pardo [30] reported the effect of $\mathrm{pH}$ on the functional sites and metal in a solution, so, at low $\mathrm{pH}$ value, hydronium ions $\left(\mathrm{H}_{3} \mathrm{O}\right)$ was able to bind to the cell wall, and thus restrict the binding of metal ions from the adsorption surface, because of charge dissimilarity. At high $\mathrm{pH}$ value, the functional sites such as carboxyl,
pH3 and 24hrs

\begin{tabular}{|c|c|c|c|c|c|}
\hline & \multicolumn{4}{|c|}{ Temperature ${ }^{\circ} \mathrm{C}$} & \\
\hline \multirow{4}{*}{ 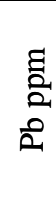 } & & 25 & 30 & 37 & LSD \\
\hline & 100 & 0.72 & \begin{tabular}{|l|l}
10.17 \\
\end{tabular} & \begin{tabular}{|l}
53.21 \\
\end{tabular} & $11.39^{*}$ \\
\hline & 150 & 5.59 & 57.25 & 59.85 & \begin{tabular}{|l}
$10.83^{*}$ \\
\end{tabular} \\
\hline & 200 & 56.75 & 58.77 & 66.01 & $8.25^{*}$ \\
\hline \multicolumn{2}{|c|}{ LSD } & $12.07 *$ & $10.86^{*}$ & $7.41 *$ & \\
\hline
\end{tabular}

$\mathrm{pH} 4.5$ and $24 \mathrm{hrs}$

\begin{tabular}{|c|c|c|c|c|c|}
\hline & \multicolumn{4}{|c|}{ Temperature ${ }^{\circ} \mathrm{C}$} & \\
\hline \multirow{4}{*}{$\begin{array}{l}\text { ă } \\
\text { 2 } \\
\text { 2. }\end{array}$} & & 25 & 30 & 37 & LSD \\
\hline & 100 & 0.4 & 1.11 & 31.39 & $10.54 *$ \\
\hline & 150 & 0.6 & 31.37 & 40.09 & 9.32* \\
\hline & 200 & 2.25 & 40.09 & 41.84 & $9.59 *$ \\
\hline \multicolumn{2}{|c|}{ LSD } & $2.25 \mathrm{NS}$ & $7.91 *$ & $7.22 *$ & \\
\hline \multicolumn{6}{|c|}{$\mathrm{pH} 3$ and $24 \mathrm{hrs}$} \\
\hline & \multicolumn{4}{|c|}{ Temperature ${ }^{\circ} \mathrm{C}$} & \\
\hline \multirow{4}{*}{ 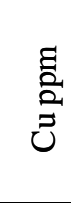 } & & 25 & 30 & 37 & LSD \\
\hline & 100 & 14.97 & 17.2 & 17.9 & $5.74 \mathrm{NS}$ \\
\hline & 150 & 24 & 26.7 & 30.24 & $5.13^{*}$ \\
\hline & 200 & 25.21 & 28.91 & 31.01 & $5.09 *$ \\
\hline \multicolumn{2}{|c|}{ LSD } & $6.73^{*}$ & $6.59 *$ & $6.82^{*}$ & \\
\hline
\end{tabular}

pH 4.5 and $24 \mathrm{hrs}$

\begin{tabular}{|c|c|c|c|c|c|}
\hline & \multicolumn{4}{|c|}{ Temperature ${ }^{\circ} \mathrm{C}$} & \\
\hline \multirow{4}{*}{$\begin{array}{l}\text { ह } \\
\text { a } \\
\text { 三 }\end{array}$} & & 25 & 30 & 37 & LSD \\
\hline & 100 & 14.97 & 19.5 & 21.01 & $5.94 *$ \\
\hline & 150 & 26.69 & 28.1 & 28.79 & $5.31 \mathrm{NS}$ \\
\hline & 200 & 26.71 & 30.01 & 30.78 & $5.63 \mathrm{NS}$ \\
\hline \multicolumn{2}{|c|}{ LSD } & $6.45^{*}$ & $7.56^{*}$ & 6.13 & \\
\hline
\end{tabular}

phosphate, and amino group were increased and the overall charge net became anions, which binds to the cationic metals by electrostatic interaction at the surface of the cell.

Lead adsorption was noticed to be inhibited at alkaline $\mathrm{pH}$ values, because of forming of peroxides, hydroxyls and non-soluble carbons [31]. It has been reported that the increased in $\mathrm{pH}$ values is lead to forms hydroxyl complexes that compete with the functional sites to bind with metals ions and therefore reduce the level of adsorption. 
Oves et al. [32] referred to the most suitable $\mathrm{pH}$ value for copper adsorption was at 6 , and they reported that the increase of $\mathrm{pH}$ value above 5 caused precipitation of lead ions. Furthermore, it has been determined that $\mathrm{pH} 5$ is an ideal value for lead adsorption by Stenotrophomonas maltophilia and B. subtilis [33]. While, another study has mentioned that the best $\mathrm{pH}$ value for lead adsorption by Bacillus megaterium was around 7 [34]. The study of Aloosh and AL-Azawi [35] determined the appropriate $\mathrm{pH}$ value for bacterial growth and survival. They found that the ideal $\mathrm{pH}$ value for $C$. freundii was 6 , and 7 for C. kosari for adsorption of lead and chromium. It has also demonstrated that the best $\mathrm{pH}$ value for lead adsorption was 5 by using of lyophilised $P$. aerugenosa [36]. It was also recorded that the ideal $\mathrm{pH}$ for copper adsorption was at 4 when using algae [26].

\section{Contact time}

The results of a current study referred to the best contact time for lead and copper adsorption using of E.coli, $P$. aeruginosa and SRB for all concentrations were $2 \mathrm{hrs}$ (Figure 3 , Table1-3). The contact time is one of the important factors affecting the heavy metal adsorption because the fast saturation of the functional sites [37], as well as the capability of empty functional sites to bind to metal ions [11]. Some of related studies were agreed that the adsorption occurs in the first hour of the contact between the metal ion and the adsorption surface [27, 38]. Other studies revealed that the adsorption will take place in less than one hour and approximately $20 \mathrm{~min}$ $[11,39]$. In contrast, other studies were reported that the adsorption occurs in more than one hour [40, 41].

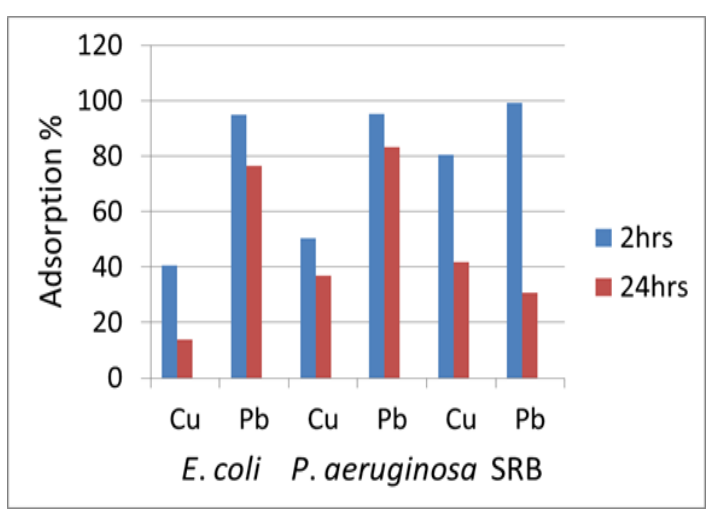

Fig. 3: Lead and Copper adsorption percentage by the studied bacteria during two contact times.

\section{Heavy metal concentration}

The increasing of heavy metal concentration leads to increase the kinetic energy in one side, and the capability of metals to bind to the solutions or solid surfaces in another side, as well as accelerate the contact and clash between the metals and the adsorption surfaces which increase the uptake of metals [33]. At low concentrations, the available ions that ready for adsorption are low, unlike the high concentrations that lead to increase the availability of ions that ready to be saturated [42].

Kirova et al. ([43] reported that the increasing of lead concentrations is due to increase the adsorption process, when lead concentration of $25 \mathrm{ppm}$ around $24.70 \mathrm{mg} / \mathrm{g}$ was adsorbed, whereas, at $50 \mathrm{ppm}$ about $48.84 \mathrm{mg} / \mathrm{g}$ was adsorbed. At $100 \mathrm{ppm}$ the adsorption portion of lead was increased to about $89.23 \mathrm{mg} / \mathrm{g}$ by Streptomyces fradiae. Furthermore, Wierzba and Latala [44] were mentioned in their study that the increasing of nickel and lead concentrations enhance the binding of functional sites with the adsorption surface. In addition, they reported that the adsorption in the life cells is better than that of dead cells, because of in the former the elements were up taken not only by adsorption but also by the intracellular process like accumulation. The results of this study referred to 
increase the range of adsorption with increasing the concentration of the heavy metal, as it showed that the highest adsorption for lead was $99.07 \%$ at $200 \mathrm{ppm}$ and $\mathrm{pH} 4.5$ and under $37^{\circ} \mathrm{C}$ for $2 \mathrm{hrs}$ by SRB (Table 3). The lowest adsorption percentage $(2.39 \%)$ for lead was observed at $100 \mathrm{ppm}, \mathrm{pH} 3,25^{\circ} \mathrm{C}$ for 24 hrs by $E$. coli.

Like in lead adsorption, the best adsorption percentage $(91.36 \%)$ for copper was obtained at $200 \mathrm{ppm}, 37^{\circ} \mathrm{C}$, $\mathrm{pH} 3$ for 2 hrs by SRB (Figure 4), whereas, the lowest percentage $(2.07 \%)$ was at $100 \mathrm{ppm}, \mathrm{pH} 3,25^{\circ} \mathrm{C}$ for $24 \mathrm{hrs}$ by $E$. coli. The above results were in agreement with the result of other studies [35]. However, Mohammed [37] was reported that the decrease in the adsorption percentage of lead from 85.5 $\%$ to $68.25 \%$ and for cadmium from $97.5 \%$ to $61.3 \%$ was due to increase the concentrations from $10 \mathrm{mg} / \mathrm{l}$ to $80 \mathrm{mg} / \mathrm{l}$ by using the crust of sunflowers as an adsorb surface.

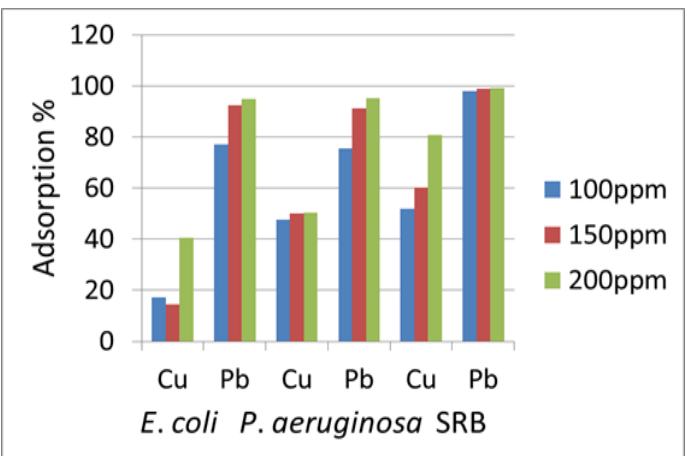

Fig. 4: The adsorption percentage of copper and lead by the studied bacteria at different concentrations

Taken into account these results, it can be clearly seen that the adsorption percentage of lead is better than of copper adsorption, and thus is due to several reasons; radius ionosphere and high electricity of lead [39]. In the study of [45], it was recorded that several changes could occur in the rate of permeability and formation of lead ligand, compared to copper. In addition to the ionization power which is increased by decrease the radius atomic radiation, and the solubility of lead nitrate in water is less than that of copper chloride, which make it more vulnerable for adsorption [26].

The results of the current study clearly showed that the ability of $P$. aeruginosa to adsorbe and remove heavy metals is better than that of $E$. coli, because it has a system that works as a regulator for heavy metal uptake by using of ATPase type technique, by which it use the ATP as a pump for metal ions. Moreover, the bacteria have a complex enzymatic system which is able to degrade more than 3000 organic materials that available in the environment. In addition to their ability to produce dimethyl disulfide (DMDS), which plays a major role in heavy metal precipitation [46[. Mohammed [47] also mentioned to the preferential capability of $P$. aeruginosa for breaking down the hydrocarbons, in comparison to $B$. subtilis and $B$. cereus. The reason behind that is due to the efficiency of $P$. aeruginosa to reduce the hydrocarbons group because of their high surface tension as a result of bioprocess on the cell surface.

SRB is distributed widely in natural and artificial environment that have sulphur [48, 49]. SRB have many applications such as adsorption process and heavy metal uptake from contaminated water. The latter is considered as a distinguisher between sulphate and sulphide, when sulphate has high solubility compared to sulphide, so the reduction of sulphate and oxidation of residual sulphide were developed to remove heavy metal [48]. The adsorption results of SRB showed high capability to adsorb lead and copper compared to the others (Table 13). This bacteria reduce sulphur element which then act as a final ion receptor, in the study of [50], SRB played a role in breaking down or substitute cadmium 
compound to be easy to adsorbe by plant, with percentage of $70 \%$. In another study, a zero valent iron (ZVI) was used by which bacteria can be prepared with the iron column, and the heavy metal acids of lead and copper were passed in the column. The use of this technique increased the efficiency of bacteria in metal remover to a percentage of $99.7 \%$ [51]. In a similar study the same bacteria were used to remove copper after addition of iron, thus, lead them to suggest that $\mathrm{SRB}+\mathrm{Fe}$ system will increase the bacterial role to $95 \%$ [52]. Another study was mentioned that copper remover is well done in the presence of iron sulphate column [53]. In addition, some researchers mentioned to use the Electron Micropial Analysis (E M P A) to decrease the data and obtained of good results for metal removal [54]. The RSB plays a great role in the chromium adsorption because the presence of iron oxide on the surface of the cell [55].

\section{Conclusion:}

The results recorded the significant differences in the temperature when sulfur bacteria was used in the adsorption of lead, and recorded a significant difference in the adsorption of copper. For heavy metals concentration, the results indicate that the highest adsorption percentage was at 200ppm concentration for both elements, and results were also showed that the type of bacteria were able to adsorb lead at higher rates than copper. Moreover, increased adsorption of metals was observed at high temperature and $\mathrm{pH} 4.5$ for a $2 \mathrm{hr}$ contact time by the studied bacteria. The three isolated bacteria were varied in their abilities to adsorb elements, the results demonstrated that the adsorption efficiency of sulfur bacteria was higher than that of $P$. aeruginosa and E. coli, while, the adsorption efficiency of $P$. aeruginosa was higher than in E.coli.
The study concluded that SRB is the most efficient bacteria to remove the $\mathrm{Pb}$ and $\mathrm{Cu}$ from the wastewater treatment plant.

\section{Acknowledgement}

The authors would like to thank the College of Science for Women, University of Baghdad and College of Education for Pure Science, University of Diyala for their support throughout the study. We thank Dr Halah AlHaideri, College of Science for Women, University of Baghdad, for her effort to revise the manuscript.

\section{References:}

[1] Osman, A. 2007. Embryo-Toxic Effects of Lead Nitrate of the African Catfish Clarias Gariepinus (Burchell, 1822). Ph.D. Thesis. HumboldtUniversity, Berlin.128p.

[2] Mapfumo, E.; Willms, W. and Chanasyk, D. 2002. Water quality of surface runoff from grazed fescue grassland watershed in Alberta. Water Quality Research Journal of Canada. 37: 543-562.

[3] Ofomaja, A. E. and Ho, Y. 2007. Effect of $\mathrm{pH}$ on cadmium biosorption by coconut copera meal. Journal of Hazardous Material. 139: 356-362.

[4] Malekzadeh, M.; Farazmand, A.; Ghafourian, H.; Shahamat, M.; Crim, C. and Colwell, R. R. 1996. Accumulation of heavy metals by a bacterium isolated from electroplating effluent. Proceeding of the Biotechnology Risk Assessment Symposium, Canada, pp: 388-398..

[5] Shartooh, S. M.; Kasim, S. A.; Obaid, R. H.; Hadi, A. A.; Abdulmajeed, A. A. 2014. Lettuce Leaves as Biosorbent Material to Remove Heavy Metal Ions from industrial wastewater. Baghdad Science Journal, 11 (3): 1164- 1170.

[6] Zouboulis, A. L.; Loukidou, M. X.; and Matis, K. A. 2004. Biosorption of toxic metals from aqueous 
solutions by bacteria strains isolated from metal-polluted soils. Process Biochemistry, 39: 909-916.

[7] Al-Haidarey, M. J. S.; Hassan, F. M.; Al- Kubaisey, A. R. A.; and Douabul, A. A. Z. 2010. The geoaccumulation index of some heavy metals in Al-Hawizeh marsh, Iraq. E-Journal of Chemistry, 7 (S1): S157-S162.

[8] Duffus, T. H. 2002. Heavy metals-A meaningless term Purs. Appl. Chem.74:793-807.

[9] Wang, J. and Chen, C. 2009. Biosorbent for heavy metals removal and their future. Biotechnol. Avd., 27 (2): 195-226.

[10] Paknikar, K.; Pethkar ${ }^{3}$, A. and Puranik, P. 2003. Bioremediation of metalliferous Wastes and products using Inactivated Microbial Biomass. Indian J. Biotechnol. 2: 426-443.

[11] Joo, J. H.; Hassan, S. H. and Oh, S. E. 2010. Comparative study of biosorption of $\mathrm{Zn}^{2+}$ by Pseudomonas aeruginosa and Bacillus cereus. Int. Biodeterior Biodegradation. 64(7):34-41.

[12] Kim, S. U.; Cheong, Y. H.; Sea; D. C.; Hur, J. S.; Heo, J. S. and cho, J. S. 2007.Characterization of heavy metals tolerance and biosorption capacity of bacterium strain CPB4 (Bacillus spp). Water science and Technology.55:105-111.

[13] Rodriques, C. E.; Quesada, A.; Rodriguez, E. 2006. Nickle biosorption by Acinetobacter baumannii and Psedomonus aeroginosa isolated from industrial waste water. Brazillian Journal of Microbiology. 37:465-467.

[14] Vieria, R. H. S. F. and Volesky, B. 2000. Biosorption: a solution to pollution? International Microbiol, 3: 17-24.

[15] Deng, X.; Zheng, Y.; Li, Q. 2006. Effect of ambient conditions on simultaneous growth and bioaccumulation of mercuric one by genetically engineered E.coli. Journal of Hazardous Materials. B136: 233238.

[16] Hossain, M. and Anantharman, N. 2005. Studies on Copper (II) biosorption using Thiobacillus ferroxidans. Journal of the University of Chemical Technology and Metallurgy, 40 (3): 227-234.

[17] Hassan, F. H.; Al- Baidhani, A. N. A. R.; and Al-Khalidi, S. H. H. 2016. Evalution industrial and domastic wastewater treatment plant of Diala's State Company of Electrical Industies, Iraq. Mesop. Environ.J., (in press).

[18] APAH (American Public Health Association). 1998. Standards methods for the examination of water and wastewater, $20^{\text {th }}$. Ed.Washington DC, USA. 1220p.

[19] Cowan and steel. 2004. Manual for the Identification of medical Bacteria, $3^{\text {rd }}$ Edition. 352p.

[20] Postgate, J. R. and Campbell, L. L. 1966. Classification of desulfovibrio species, the nonsporulating sulphatereducing bacteria. Bacteriol. Rev., 30: $732-738$.

[21] Turan, P.; Dogan, M.; and Alkan, M. 2007. Uptake of trivalent chromium ions from aqueous solutions using Kaolinite. J. Hazard Mater, 148: 56-63.

[22] Mahmoad, M. N.; Abdel- Samie, M. E.; El-Mokadem, M. T.; AbdelRaheim, S.S. and Ghazy, E.A. 2008 . Development Of Biofilm (Bf) On Mild Steel Surfaces Immersed In Suez Gulf Sea Water. J. Abbl. Sc. Res., 4: 1799-1804.

[23] Paranthaman, S. R. and Karthikeyan, 2015. Bioremediation of heavy metal in paper mill effluentusing Pseudomonas spp. Microbioz. Journals International Journal of Microbiology. 1(4):1-5.

[24] Ilamathi, R.; Nirmala, G. S. and Muruganandam, L. 2014. Heavy 
metals biosorption in liquid solid Fluidized bed by immobilized consortia in Alginate beads. Int. J. Chem Tech Res., 6 (1): 652-662.

[25] Hameed, Q. A. 2015. Bioremoval of Chromium and Lead by Bacteria Pseudomonas aeruginosa in Respect to Its Genotype. MSc Thesis, College of Science, University of Baghdad.

[26] Sulaymon, A. H.; Mohammed A. A.; Al-Musawi, T. J. 2013. Competitive biosorption of lead, cadmium, copper, and arsenic ions using algae, Environ. Sci. and Pollut. Res.Vol. 20, PP.3011-3023.

[27] Abdul Sattar, J. A. 2013. Toxic Metal Pollution Abatement Using Sour Orange Biomass. Journal of AlNahrain University. 16 (30):.56-64.

[28] Vijayaraghavan, K. and Yun, Y.S. 2008. Bacterial biosorbents and biosorption. Biotechnol Adv. 26(3):266-291.

[29] Sri Kumaran, N.;

Sundaramanickam, A. and Bragadeeswaaran, S. 2011. Absorption studies on heavy metals by isolated bacterial strain (Pseudomonas sp.) from Uppanar estuarine water, southeast costal of India. J. Appl. Sci., 6 (4): 471- 476.

[30] Pardo, R.; Herguedas, M.; Barrado, E.and Vega, M. 2003. Biosorption of cadmium, copper, lead and zinc by inactive biomass of Pseudomonas

[31] Daboor,S.M.2014. Application of bacterial biomass as a potential heavy metal bio-removal agent. Afr. J. Microbiol. Res.8(22):2229- 2237.

[32] Oves, M.; Khan, M. S. and Zaidi, A. 2013. Biosorption of heav metals by acillus thuringiensis strain OSM29 originating from industrial effulent contaminated north Indian soil. Aidi . Biol. Sci., 20121-29.

[33] Wierzba, S. and Latala, A. 2010. Biosorption lead(II) and nikel(II) from an aqueous solution by bacterial biomass. Pol. J. Chem. Tech.12 (3):72-78.
[34] Sati, M.; Verma, M. and Rai, J. P. N. 2015. Biosorption of pb (II) ions from aqueous solution on to free and immobilized cells of Bacillus megaterium. Int.1 J. Rec. Sci. Res.,.5 (7)1286-1292.

[35] Aloosh, Maiada, K. H. and AlAzzawi, Mohammad, N. A. 2015. Removal of Lead and Chromium From Industrial Wastewater by LocallyCitrobacter spp.Isolates. Iraqi J. Sci., 56 (2A): 983-997.

[36] Peter, A. K; Kocsis, B; Kilar, F., and Pernyesz, T. 2014. Bioadsorption characteristics of Pseudomonas aeruginosa PAO1. J Serb. Chem. Soc. 79 (4): 495-508.

[37] Hefne, J. A.; Mekhemer, W. K.; Alandis, N. M.; Aldayel, O. A. and Alajyan, T. 2010. Removal of silver (I) from aqueous solutions by natural bentonite. JKAU: Sci, 22 (1): 155-176.

[38] Vasudevan, A.; Dineshkumar, K.; Mohanalakshmi, N. and Hopper, W. 2014. Identification of natural compound inhibitors for multidrug efflux pumps of Escherichia coli and Pseudomonas aeruginosa using in silico high-throughput virtual screening and in vitro validation. PLoS ONE, 9 (7):e101840. DOI: 10.1371/journal.pone.0101840.

[39] Mohammed, A. A. 2015.

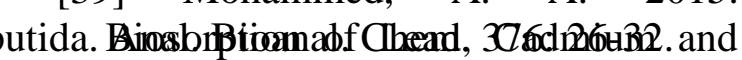
Zinc onto Sunflower Shell, Iraqi Journal of Chemical and Petroleum Engineering. 16 (1): 91- 105.

[40] Colak, F.; Atar, N.; Yazicioglu, D. and Olgun, A. 2011. Biosorption of lead from aqueous solutions by Bacillus strains possessing heavymetal resistance. Chemical Engineering Journal. 173: 422-428.

[41] Dlamini, N. P.; Mamba, B. B. and Mulaba, A. F. 2010. The effect of silica concentration on the biosorption of $\mathrm{Cu}^{+2}$ and $\mathrm{Co}^{+2}$ from aqueous solutions mediated by strains 
of Bacillus. Water Sal., 36 (4): 445450.

[42] Balakrishnan, V.; Arivoli, S.; Begum, A. and Ahmed, A. 2010. Studies on the adsorption mechanism of $\mathrm{Cu}$ (II) ions by a new activated carbon. J. Chem. Pharm. Res. 2 (6): 176-190.

[43] Kirova, G; Velkova, Z; Sto, M. and Gochev, V. 2015. Biosorption of $\mathrm{Pb}$ (II) ions from aqueous solutions by waste biomass of Streptomyces fradiae pretreated with $\mathrm{NaOH}$. Biotechnology and Biotechnological Equipment, 29 (4): 1-7. DOI: 10.1080/13102818.2015.1036775

[44] Wierzba, S. and Latala, A. 2010. Biosorption lead(II) and nikel(II) from an aqueous solution by bacterial biomass. Pol. J. Chem. Tech.12 (3): $72-78$.

[45] Mohammed, A. and Ali, A. 2013. Biotreatment of AL-KARAMA teaching hospital wastewater using aerobic pached bed. J. Baghdad for Sci. , 10: 144-151.

[46] Al- Ghizawi, G. J. and Al- Azawi, A. J. S. 2014. The ability some isolated bacteria types from ShattAl-Arab and marine water, to biosorption for some heavy metals.J. Basrah Res. (Sci.), 40(3B): 116- 130.

[47] Mohammed, M. 2014. Treatment of polluted water with hydrocarbon by using some species of bacteria. PhD. Thesis, College f Science, University of Baghdad. 213p.

[48] Muyzer, G. and Stams, A. J. M. 2008. The ecology and biotechnology of sulphate- reducing bacteria. Nature Reviews Microbiology, 6: 441-454. doi:10.1038/nrmicro1892

[49] Bottrell, S. H.; Mortimer, R.; Davies, I. M. and Krom, M. D. 2009.
Sulphur cycling in organic -rich marine sediments from a Scottish fjord. Sedimentology, 56 (4): 11591173. DOI: $10.1111 / \mathrm{j} .1365-$ 3091.2008.01024.x

[50] Jiang, W. and Fan, W .2008. Bioremediation of heavy metalcontaminated soils by sulfatereducing bacteria.Ann N. Y. Acad. Sci., 1140:446-54. doi: 10.1196/ annals.1454.050.

[51] Ayala-Parra P., Sierra-Alvarez R., and Field, J. A. 2016. Treatment of acid rock drainage using a sulfatereducing bioreactor with zero-valent iron. Journal of Hazardous Materials, 308:97-105.

[52] Bai, H.; Kang, Y.; Quan, H.. and Feng, Y. 2013. Bioremediation of copper-containing wastewater by sulphate reducing bacteria couple with iron. J. Envirn. Manag., 129C: 350-356.

[53] Moreau, J. W.; Fournelle, J. H. and Banfield, J. F. 2013. Quantifying heavy metals sequestration by sulfate-reducing bacteria in an acid mine drainage-contaminated natural wetland. Front Microbiol. 12 March, E published. doi: 10.3389/fmicb.2013.00043.

[54] Donovan, J. J.; Kremser, D.; Fournelle, J. and Goermann, K. 2012. Probe for EPMA User's uide and Reference. Eugene: Enterprise Edition, 429.

[55] Ajouyed, O.; Hurel, C.; Ammari M.; Allal, L. B.; Marmier, N. 2010. Sorption of $\mathrm{Cr}$ (VI) onto natural iron and aluminum (oxy) hydroxides: effects of $\mathrm{pH}$, ionic strength and initial concentration. Journal of Hazardous Materials 174: 616-622. 


\title{
الادمصاص الحيوي للعناصر الثقيلة من مياه الفضلة الصناعية باستخدام بعض الفض الانواع البكتيرية
}

\author{
*عنان نعمة عبد الرضا البيضاني
}

فكرت مجيد حسن*

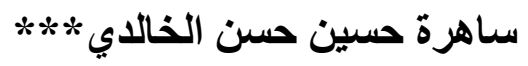

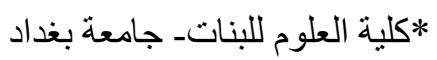

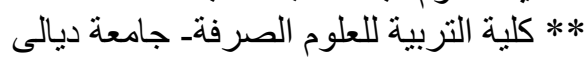

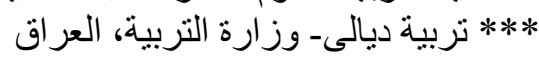

اختبرت ثلاثة أنو اع من البكتريا المعزولة وهي Escherichia و Pseudomonas aeruginosa

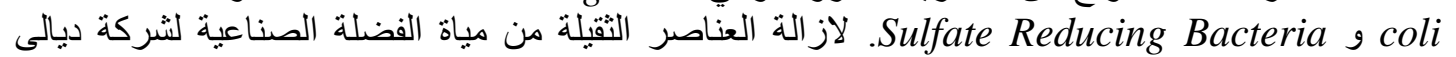

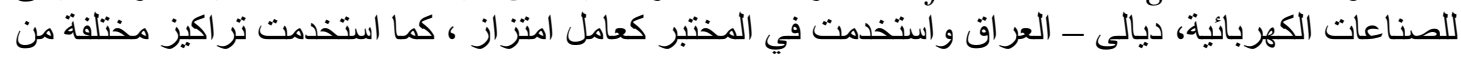

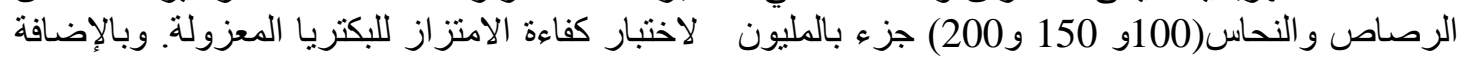

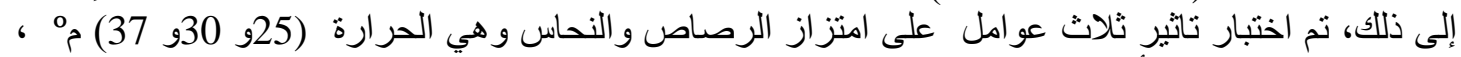

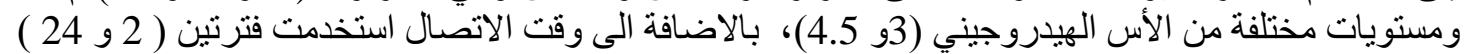
ساعة. تم الحصول على اعلى مستوى لامتز از الرصاص وبالنسب

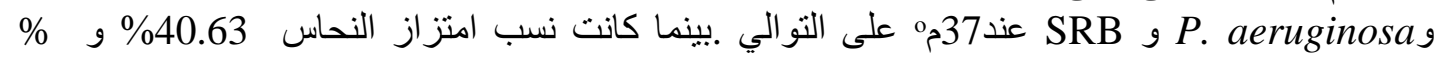

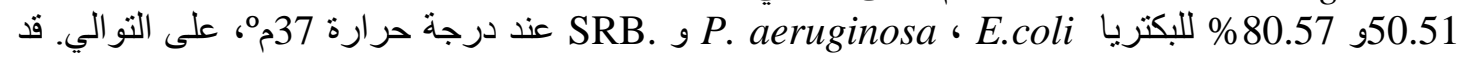

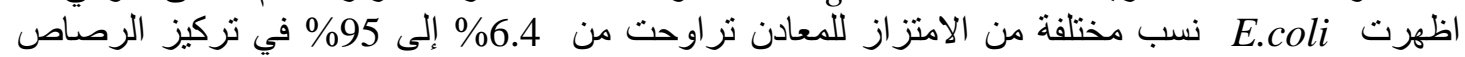

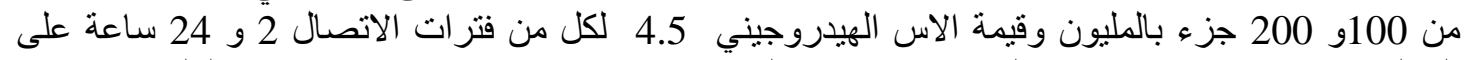

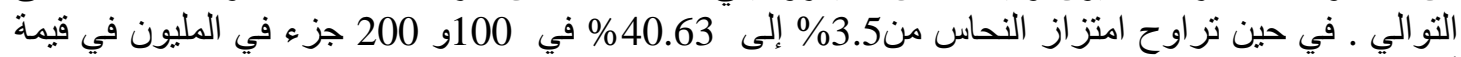

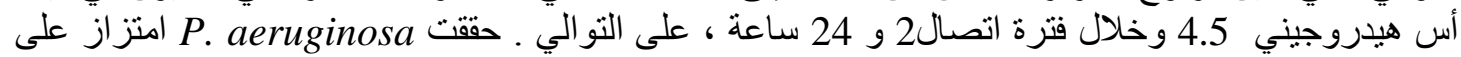

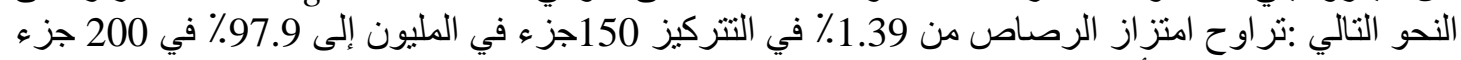

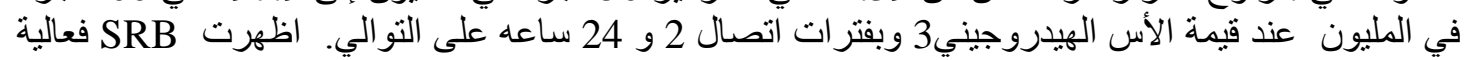

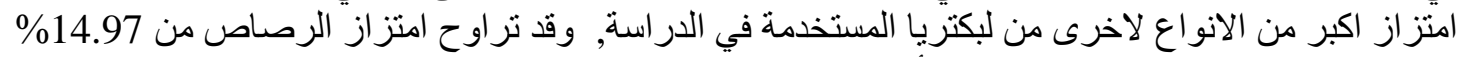

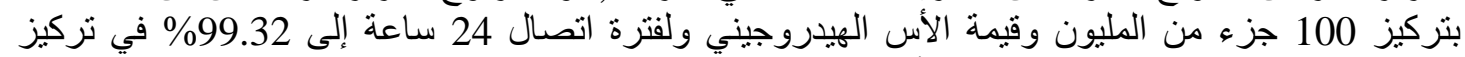

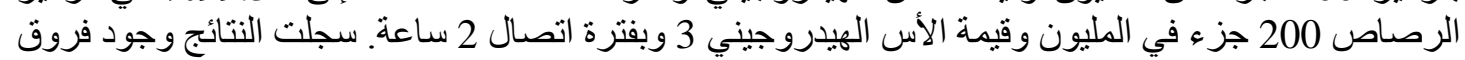

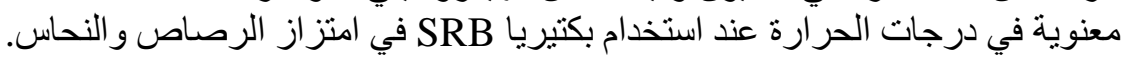

الكلمات المفتاحية: المعالجة البايولوجية، وحدة المعالجة، E. coli, P. aeruginosa and SRB ، الفضلة الصناعية 